UDC 577

\title{
Intranuclear localization of transcription factories and immunoglobulin heavy chain gene alleles during human B-cell maturation
}

\author{
A.V. Pichugin $1,2,3$, O. V. Iarovaia ${ }^{1,2,4}$, I. V. Sklyar ${ }^{1,2,4}$, G. Lacombe ${ }^{5}$, \\ S. V. Razin ${ }^{2,4,6}$, T. Fest ${ }^{5}$, M. Lipinski ${ }^{1,2}$, Y. S. Vassetzky ${ }^{1,2,6}$ \\ ${ }^{1}$ CNRS UMR 8126, Universit Paris-Sud 11, Institut Gustave Roussy \\ 114, rue Edouard Vaillant, Villejuif, France, 94805 \\ 2 LIA 1066 French-Russian Joint Cancer Research Laboratory \\ Villejuif, France-Moscow, Russian Federation \\ ${ }^{3}$ Peter the Great St. Petersburg Polytechnic University \\ 29, Polytechnicheskaya Str, St.Petersburg, Russian Federation, 195251 \\ ${ }^{4}$ Institute of Gene Biology, Russian Academy of Sciences \\ 34/5, Vavilova Str., Moscow, Russian Federation, 119334 \\ 5 INSERM U917, Université de Rennes \\ 2, avenue du Professeur Léon Bernard F - 35043 Rennes, France \\ ${ }^{6}$ Faculty of Biology, M. V. Lomonosov Moscow State University \\ Leninskie Gory, Moscow, Russian Federation, 119991 \\ vassetzky@igr.fr
}

\begin{abstract}
Immunoglobulin heavy chain (IGH) gene locus is expressed monoallelically in human B cells. Aim. To study the role of nuclear organization in regulation of the $I G H$ expression during B-cell differentiation. Methods. Immunofluorescence in situ hybridization on 3D-preserved nuclei (3D immuno-FISH). Results. Active RNA polymerase II (Pol II) molecules and the IGH locus were detected in the periphery of the nucleoli at some stages of B-cell differentiation. Conclusions. We observed significant changes in the pattern of distribution of RNA polymerase II in the nucleus during B-cell differentiation, but no preferential co-localization of the productive IGH allele with the transcription factories in the vicinity of the nucleolus and in the nucleoplasm was observed.
\end{abstract}

Ke y w o r d s: Immunoglobulin heavy chain gene, transcription, nucleolus, B-cell maturation

\section{Introdution}

Nucleus is divided into transcriptionally active and repressive compartments (reviewed in [1]). Transcriptional activation is associated with the euchromatic regions of the nucleus and transcriptional factories (reviewed in [2]). A functional immunoglobulin heavy chain is produced monoallelically (Rajewsky 1996); it undergoes regulated transcription during the $\mathrm{B}$ lymphocyte development. Transcription might be controlled by localized al- terations in the chromatin structure. Whether such a mechanism is sufficient to account for the allele-specific transcription of the $I G H$ locus is currently unknown. In mice, the localization of productive and non-productive $I G H$ alleles changes during B-cell maturation. A non-productive $I G H$ allele is located close to the nuclear periphery whereas the productive $I G H$ allele is associated with euchromatin [5-7]; much less is known about the role of nuclear organization in the human $I G H$ allelic transcription. We have recently found that the $I G H$ locus was located

(C) 2016 A. Pichugin et al.; Published by the Institute of Molecular Biology and Genetics, NAS of Ukraine on behalf of Biopolymers and Cell. This is an Open Access article distributed under the terms of the Creative Commons Attribution License (http://creativecommons.org/licenses/by/4.0/), which permits unrestricted reuse, distribution, and reproduction in any medium, provided the original work is properly cited 
close to the nucleolus in both naïve and activated B-cells [8] as well as in B-cell lymphoma [9]. However, the functional significance of this localization remains unknown.

Given the evidence that the eukaryotic gene activity can be regulated by subnuclear compartmentalization (reviewed in [10]), we investigated whether the perinucleolar localization of the $I G H$ locus might play a role in controlling its transcription. Here we have used 3D-fluorescence in situ hybridization (3D-FISH) combined with immunofluorescence to co-detect the localization of the $I G H$ alleles, nucleoli and transcription factories at different stages of B lymphocyte maturation.

\section{Materials and Methods}

\section{In vitro B-cell differentiation}

Peripheral blood cells from healthy volunteers were purchased from the French Blood Center. B-cells at different stages of differentiation were obtained essentially as described in [11]. Plasmocytes were isolated from peripheral blood using the CD138+ Plasma Cell Isolation Kit (Miltenyi Biotech).

\section{Three-dimensional fluorescence in situ hybridi- zation (3D-FISH) and immuno-detection}

3D FISH experiments were essentially carried out as described elsewhere [9]. The stained probes used in this study (RP11-346I20 that recognizes the constant region of the IGH locus and RP11-259B19 for the $\mathrm{J} / \mathrm{D}$ region) were purchased from Blue Gnome (Cambridge, UK). Nucleoli were detected using mouse anti-B23 antibody (Sigma, St Louis, MO) and chicken anti-mouse Alexa 647 (Molecular Probes, Carlsbad, CA). The Pol II antibodies were from Active Motif, Carlsbad, CA. The images were processed and analyzed as described in [9].

\section{Results and Discussion}

In order to study whether the $I G H$ localization vs. transcription factories undergoes dynamic changes linked to its functional status, we have followed the localization of the $I G H$ alleles in human cells during
B-cell maturation in vitro [11]; this system allows reproducing the major stages of B-cell differentiation in lymph nodes. We used B-cells at the following stages: naive B-cells $\left(\right.$ Day $\left._{0}\right)$, activated B-cells $\left(\right.$ Day $\left._{1}\right)$, cells at the stage of plasmoblast differentiation $\left(\mathrm{Day}_{4}\right)$, and cells at the stage of somatic hypermutation and class switch recombination $\left(\right.$ Day $\left._{5 / 6}\right)$.

The $I G H$ locus being located close to a nucleolus at some stages of B-cell maturation [8], we wondered whether its transcription would actually take place in the perinucleolar region which, with some exceptions [9] is not known for being prone to [the] RNA polymerase II (Pol II)-dependent gene transcription [12]. To test this, B-cells were stained using the B23 antibody that decorates nucleoli and the antibody to the phosphorylated C-terminal domain of the transcriptionally-active form of Pol II. These active Pol II molecules are present in nuclear foci called transcription factories, where active transcription takes place (for review see [2]). Typical Pol II staining patterns are presented in Fig. 1. Uniform staining of active Pol II molecules was detected in the immediate vicinity of nucleoli in naïve $\mathrm{B}$ lymphocytes at $\mathrm{Day}_{0}$. Activation of B-cells at Day ${ }_{1}$ led to a decrease in Pol II staining with transcription factories being organized in clusters, some of them adjacent to the nucleolus. At Day ${ }_{4}$, Pol II was excluded from the perinucleolar regions; at Day ${ }_{5 / 6}$, this exclusion zone disappeared and intense Pol II staining surrounded the nucleolus. Finally, in plasmocytes, Pol II staining concentrated in the center of the nucleus, with some staining around the nucleolus (Fig. 1).

Next, the proximity between the $I G H$ alleles and Pol II foci at different stages of B-cell differentiation was evaluated using an immuno-FISH approach whereby nucleoli, Pol II clusters, and the productive $I G H$ alleles were all simultaneously visualized. [The] Signals from the productive $I G H$ allele (green), and Pol II (white) were scored in relation to their proximity to the nucleolus (blue). The results are summarized in Fig. 2. These data indicate that the productive $I G H$ allele is preferentially colocalized with the transcription factories at the nucleolus in naïve B-lymphocytes at Day $_{0}$ and at the SHM and CSR stages at Day ${ }_{5 / 6}$. 
Day $_{0}$

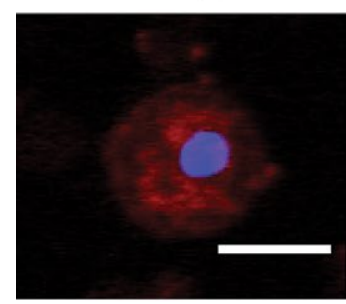

Day $_{1}$

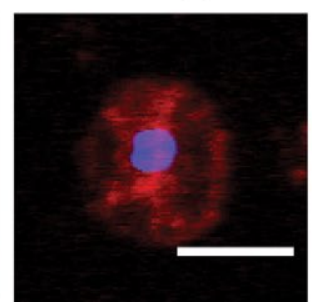

Day $_{4}$

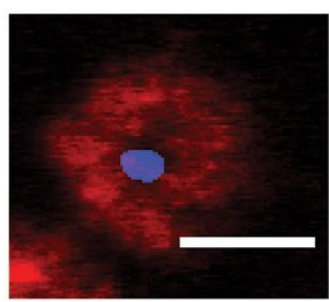

$\operatorname{Day}_{5 / 6}$

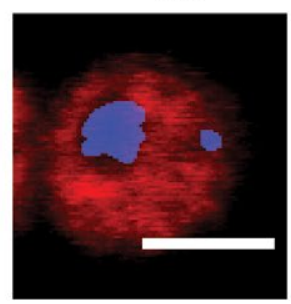

Plasmocytes

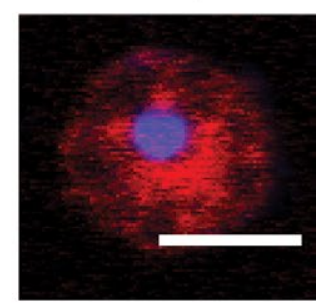

Fig. 1. Localization of transcription factories and nucleoli during induced B-cell maturation. Active RNA polymerase II (green) and nucleoli (B23, blue) were simultaneously revealed by immunostaining. Typical images are shown. Scale bar $=5 \mu \mathrm{m}$

B-cells are monospecific, i.e. they produce one antibody per cell. This is due to allelic exclusion of immunoglobulin $(\mathrm{Ig})$ heavy $(\mathrm{H})$ and light $(\mathrm{L})$ chain genes established during $\mathrm{V}(\mathrm{D}) \mathrm{J}$ recombination (reviewed in [13]). While the somatic generation of functional $\mathrm{Ig}$ genes by $\mathrm{V}(\mathrm{D}) \mathrm{J}$ recombination is a subject to allelic exclusion, the expression of Ig loci per se does not appear to be monoallelic as Ig transcripts are expressed from both alleles whereas only one of the two Ig al- leles is functional [14]. The molecular and cellular mechanisms regulating allelic exclusion during V(D)J recombination are well studied [15], much less is known on how these mechanisms operate at the final stages of B-cell differentiation. DNA methylation [16], chromatin organization [17] and subnuclear localization [5-8] might contribute to this process.

The positioning of one allele in the vicinity of a nucleolus, a statistically significant difference be-
A

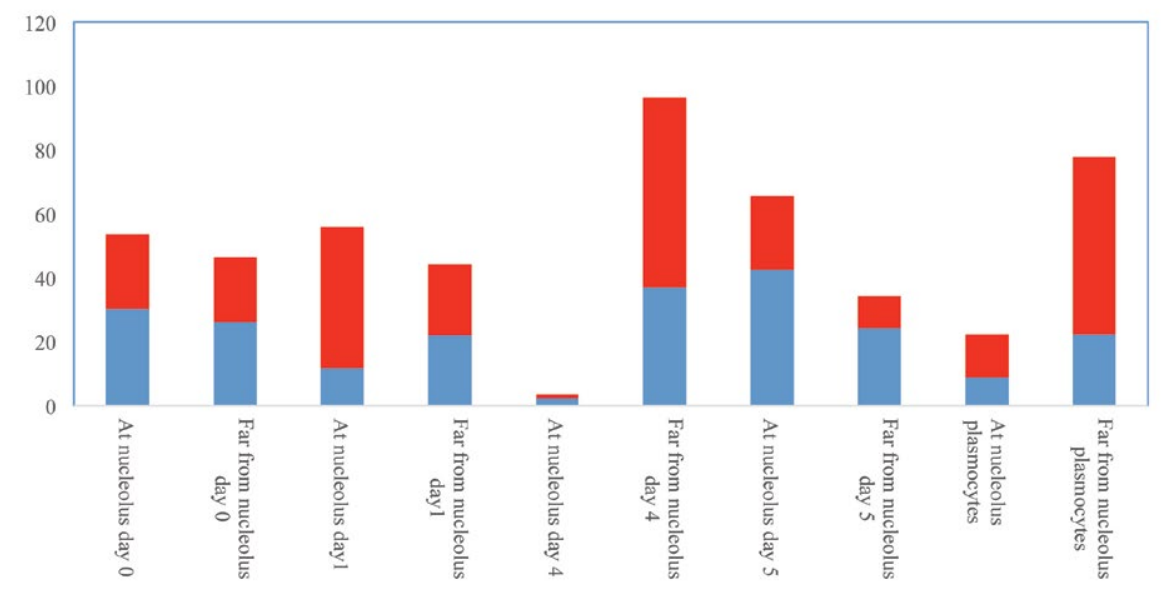

B

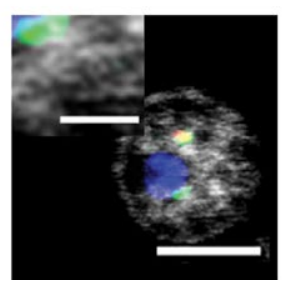

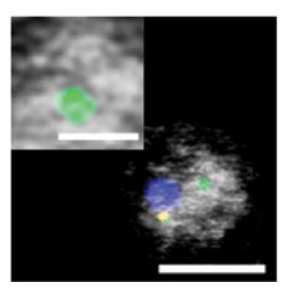

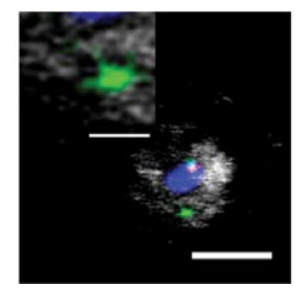

Fig. 2. Association of IGH alleles with the RNA polymerase II during B-cell maturation. A, quantitation of colocalization of the productive (red) and non-productive (blue) IGH alleles with the nucleolus and transcription factories. B, Representative images of the productive (green) and non-productive (merged green and red) IGH alleles with nuclei stained for nucleolus (bleu) and RNA polymerase II (gray) at different stages of B-cell maturation. Scale bar $=5 \mu \mathrm{m}$ and $1 \mu \mathrm{m}$ in zoom. 
tween the two alleles, may be linked to the IGH expression. Indeed, transcriptionally active Pol II clusters could be observed in the vicinity of the nucleolus in lymphoid cells [9]. It is also known that nuclear factors localized in and around the nucleolus, such as nucleolin, are essential for [the] $I G H$ transcription [18]. Using immuno-FISH experiments, we analyzed the localization of the two alleles with clusters of transcriptionally active Pol II molecules (transcription factories, see [2] for review). We could not observe any preferential localization of the productive IGH allele with the transcription factories in the vicinity of the nucleolus and in the nucleoplasm. At the same time, the pattern of distribution of RNA polymerase II changed during B cell maturation, with the most striking feature being the exclusion of active RNA Pol II molecules from the perinucleolar region in activated B cells at Day 4 . We have also detected the presence of active Pol II clusters in the periphery of nucleoli that in normal cells is mostly occupied by heterochromatin [12] and therefore is not prone to the Pol II transcription. Further studies are necessary to establish a link between transcriptional activity and subnuclear organization of the $I G H$ alleles.

\section{Acknowledgements}

This work was supported by the grant \#14-24-00022 Russian Science Foundation (RSF).

\section{REFERENCES}

1. Razin SV, Vassetzky YS. 3D genomics imposes evolution of the domain model of eukaryotic genome organization. Chromosoma. 2016. doi:10.1007/s00412-016-0604-7

2. Razin SV, Gavrilov AA, Pichugin A, Lipinski M, Iarovaia OV, Vassetzky YS. Transcription factories in the context of the nuclear and genome organization. Nucleic Acids Res. 2011;39(21):9085-92.

3. Hosokawa Y, Arnold A. Mechanism of cyclin D1 (CCND1, PRAD1) overexpression in human cancer cells: analysis of allele-specific expression. Genes Chromosomes Cancer. 1998;22(1):66-71..

4. Rajewsky $K$. Clonal selection and learning in the antibody system. Nature. 1996;381(6585):751-8.

5. Hewitt SL, Yin B, Ji Y, Chaumeil J, Marszalek K, Tenthorey J, Salvagiotto G, Steinel N, Ramsey LB, Ghysdael J, Farrar MA, Sleckman BP, Schatz DG, Busslinger $M$,
Bassing CH, Skok JA. RAG-1 and ATM coordinate monoallelic recombination and nuclear positioning of immunoglobulin loci. Nat Immunol. 2009;10(6):655-64.

6. Kosak ST, Skok JA, Medina KL, Riblet R, Le Beau MM, Fisher $A G$, Singh $H$. Subnuclear compartmentalization of immunoglobulin loci during lymphocyte development. Science. 2002;296(5565):158-62.

7. Skok JA, Brown KE, Azuara V, Caparros ML, Baxter J, Takacs K, Dillon N, Gray D, Perry RP, Merkenschlager M, Fisher $A G$. Nonequivalent nuclear location of immunoglobulin alleles in B lymphocytes. Nat Immunol. 2001;2(9):848-54.

8. Sklyar I, Iarovaia OV, Gavrilov AA, Pichugin A, Germini D, Tsfasman T, Caron $G$, Fest T, Lipinski M, Razin SV, Vassetzky YS. Distinct patterns of colocalization of the CCND1 and CMYC genes with their potential translocation partner IGH at successive stages of B-Cell differentiation. J Cell Biochem. 2016.

9. Allinne J, Pichugin A, Iarovaia O, Klibi M, Barat A, Zlotek-Zlotkiewicz E, Markozashvili D, Petrova N, Camara-Clayette V, Ioudinkova E, Wiels J, Razin SV, Ribrag V, Lipinski M, Vassetzky YS. Perinucleolar relocalization and nucleolin as crucial events in the transcriptional activation of key genes in mantle cell lymphoma. Blood. 2014; 123(13):2044-53.

10. Ulianov $S V$, Gavrilov AA, Razin $S V$. Nuclear compartments, genome folding, and enhancer-promoter communication. Int Rev Cell Mol Biol. 2015;315:183-244.

11. Le Gallou S, Caron G, Delaloy C, Rossille D, Tarte K, Fest $T$. IL-2 requirement for human plasma cell generation: coupling differentiation and proliferation by enhancing MAPKERK signaling. J Immunol. 2012;189(1):161-73.

12. Politz JC, Scalzo D, Groudine M. The redundancy of the mammalian heterochromatic compartment. Curr Opin Genet Dev. 2015;37:1-8.

13. Schlissel MS. Regulating antigen-receptor gene assembly. Nat Rev Immunol. 2003;3(11):890-9.

14. Daly J, Licence S, Nanou A, Morgan G, Mårtensson IL. Transcription of productive and nonproductive VDJ-recombined alleles after $\mathrm{IgH}$ allelic exclusion. EMBO J. 2007;26(19):4273-82.

15. Vettermann C, Schlissel MS. Allelic exclusion of immunoglobulin genes: models and mechanisms. Immunol Rev. 2010;237(1):22-42.

16. Snider L, Asawachaicharn A, Tyler AE, Geng LN, Petek LM, Maves L, Miller DG, Lemmers RJ, Winokur ST, Tawil R, van der Maarel SM, Filippova GN, Tapscott SJ. RNA transcripts, miRNA-sized fragments and proteins produced from D4Z4 units: new candidates for the pathophysiology of facioscapulohumeral dystrophy. Hum Mol Genet. 2009; 18(13):2414-30.

17. Woo CJ, Martin A, Scharff MD. Induction of somatic hypermutation is associated with modifications in immunoglobulin variable region chromatin. Immunity. 2003;19(4):479-89. 
18. Hanakahi LA, Maizels $N$. Transcriptional activation by LR1 at the Emu enhancer and switch region sites. Nucleic Acids Res. 2000;28(14):2651-7.

\section{Внутрішньоядерна локалізація транскрипційних фабрик і алелей гену важкого ланцюгу імуноглобуліну в процесі дозрівання В-клітин людини}

А. В. Пичугін, О. В. Ярова, І. В. Скляр, Г. Лякомб, С. В. Разин, Т. Фест, М. Липинскій, Є. С. Васецький

Лише один аллель гену важкого ланцюгу імуноглобуліну (IGH) експресується в В-клітинах людини. Мета. Вивчити роль ядерної організації у регуляції експресії IGH при диференціюванні B-клітин. Методи. Імунофлуоресцентна гібридизація in situ (3D immuno-FISH). Результати. Активна форма РНК-полімерази II (Pol II) і ген IGH були виявлені на периферії ядерець на деяких стадіях диференціювання В-клітин. Висновки. Ми спостерігали значні зміни в характері розподілу РНК-полімерази II в ядрі під час диференціювання В-клітин. При цьому, не спостерігалося мажорної локалізації продуктивного алелі IGH 3 транскрипційними фабриками ні ву безпосередній близькості від ядерець, ні в нуклеоплазмі.

К л юч о в і с л о в а: гени важких ланцюгів імуноглобуліну, транскрипція, ядро, дозрівання В-клітин

\section{Внутриядерная локализация транскрипционных} фабрик и аллелей гена тяжелой цепи иммуноглобулина В процессе созревания В-клеток человека

А. В. Пичугин, О. В. Яровая, И. В. Скляр, Г. Лякомб, С. В. Разин, Т. Фест, М. Липинский, Е. С. Васецкий

Лишь один аллель гена тяжелой цепи иммуноглобулина (IGH) экспрессируется в Б-клетках человека. Цель. Изучить роль ядерной организации в регуляции экспрессии IGH в процессе дифференцировки В-клеток. Методы. Иммунофлуоресцентная гибридизация in situ (3D immuno-FISH). Результаты. Активная форма РНК-полимеразы II (Pol II) и ген IGH были обнаружены на периферии ядрышек на некоторых стадиях дифференцировки В-клеток. Выводы. Мы наблюдали значительные изменения в характере распределения РНК-полимеразы II в ядре во время дифференцировки В-клеток. При этом, не наблюдалось премущественной локализации продуктивного аллеля IGH c транскрипционными фабриками ни в непосредственной близости от ядрышек, ни в нуклеоплазме.

К л юч е в ы е с л о в а: гены тяжелых цепей иммуноглобулина, транскрипция, ядро, дозревание В-клеток

Received 14.02.2016 